\title{
A History of Vampires and Their Transformation From Solely Monsters to Monstrous, Tragic, and Romantic Figures
}

\author{
Mary McFadden, BA in English ${ }^{1}$ \\ ${ }^{1}$ English, Dixie State University \\ Keywords: giaour, varney the vampire, dracula, vampire archetype, vampire lore, folklore, joseph campbell, carl jung, archetype, vampire \\ https://doi.org/10.36898/001c.22205
}

Curiosity: Interdisciplinary Journal of Research and Innovation

Vol. 2, 2021

\begin{abstract}
Throughout the history of vampire stories-from folklore to literary fiction - the portrayal of these inhuman creatures has metamorphosed from Carl Jung's myth, born of the Shadow archetype, into three distinct vampiric archetypes, none of which have completely left their mythic origins behind. These archetypes present themselves as the monster vampire, the tragic vampire, and the romantic vampire. By examining the etymology of the word vampire, ancient vampire folklore, early to modern vampire literature, and early to contemporary vampire cinema, this paper will show that the vampire is no longer relegated to the role of antagonist to the story's protagonist. The vampire could be the tragic anti-hero or the protagonist of a story. Many early folklores about vampires are represented by stories humankind told to explain evil and misfortune visited upon their family. However, when the vampire entered early literary fiction, authors began to exercise their power to manipulate the vampire narrative, creating new vampire constructs. This shift in vampire characterizations is an allegorical commentary on man's fight to overcome his sinful nature by seeking salvation through redemption.
\end{abstract}

While some researchers note the existence of a vampire archetype, Carl Jung, founder of analytical psychology, believed that monsters, such as the vampire, are not archetypes themselves, but rather myths, born of archetypes. While Carl Jung's beliefs would classify a vampire as a myth, I intend to show that early to modern stories of vampires show a gradual shift from the monster myth to three separate vampire portrayals/archetypes. One portrayal of vampires remaining that of the terrifying creature of origin, as is characterized by Carl Jung's Shadow archetype; another portrayal being the tragic and tortured Byronic hero-or antihero; and the last progresses through the first two stages into the modern, beguiling, often-romanticized, literary figures of fantasy, the heroic vampire. I intend to show that these three distinct portrayals, though never fully leaving their mythic origins behind, have become their own archetypes, and the development of these archetypes mirrors humankind's path to finding redemption from their own sinful natures, or dark desires, whether based in Judeo-Christian beliefs, other religious beliefs, or a secular moralistic belief system.

Carl Jung believes there are four main archetypes: The Self, the Persona, the Shadow, and the Anima/Animus. These archetypes are primordial images - archaic remnants imprinted on the unconscious mind, the part of the mind where automatic processing occurs. These primordial images are passed down from our ancestors. Jung states: 
The term "archetype" is often misunderstood as meaning a certain definite mythological image or motif. But this would be no more than a conscious representation... The archetype is, on the contrary, an inherited tendency of the human mind to form representations of mythological motifs-representations that vary a great deal without losing their basic pattern. (Jung, 1968, p. 120)

Jung claims that every personality has a dark side that is the gateway to the unconscious mind and dreams. Through this gateway, the archetypal Shadow figure enters our dreams. Myths are not themselves archetypes. They are created by archetypes. The Shadow archetype is the hidden part of the human psyche-the part we fear for its obscurity. This fear causes our mind to create myths to represent this hidden part of our psyche (Jung, 1968, p. 38). Following Jung's logic, a vampire cannot be an archetype in itself; instead, it is a myth born of the Shadow archetype.

So, what makes the vampire, or any other creature of myth, the embodiment of Carl Jung's Shadow archetype? Tales of evil creatures abound in the time before Christianity. They are the representation of early humankind's darker side; the images Jung claims are passed down to their descendants through their DNA, just as according to Lamentations 5:7 in the Bible, the child bears the iniquities of their father (English Standard Version Bible, 2001, Lamentations 5:7). These iniquities are our sin, and Jung's Shadow archetype might very well be itself a representation of this sin and the vampire myth its manifestation.

In his book The Power of Myth, a manuscript of a conversation between Joseph Campbell, best known for his theory of the archetypal hero's journey, and journalist Bill Moyers, Campbell claims:

These bits of information from ancient times, which have to do with the themes that have supported human life, built civilizations, and informed religions over the millennia, have to do with deep inner problems, inner mysteries, inner thresholds of passage, and if you don't know what the guide signs are along the way, you have to work it out for yourself. (Campbell \& Moyer, 1998, p. 4)

To this, Moyer interprets Campbell's meaning to be, "[W]e tell stories to try to come to terms with the world, to harmonize our lives with reality" (Campbell \& Moyer, 1998, p. 4). It is in humankind's nature to ask, "Why is this happening?" In that desire to reconcile the cognitive dissonance felt when we cannot unite what we see to what we understand, our mind searches for new comprehension through the creation of myths. 


\section{Early Vampire Folklore}

Many countries and cultures have some form of vampire folklore in their history. These stories, as Campbell and Moyers suggest, have origins in the fears of those who are just trying to make sense of the world around them. Here are just a few examples.

\section{Abhartach (Celtic)}

Abhartach, a jealous dwarfish, cruel chieftain, and sorcerer, from the Irish town of Slaghtaverty in Londonberry, ruled during the $5^{\text {th }}$ and $6^{\text {th }}$-centuries. Some stories say he fell to his death when he climbed a ledge outside his wife's bedroom window to catch her cheating on him. Other versions of his tale say that a neighboring chieftain slew him. Abhartach was buried in an upright, rather than the typical prone position, as were many rulers of that time. The next day, the sorcerer returned from the grave and demanded that his subjects slit their wrists and fill a bowl with their blood for his consumption. The blood was necessary to sustain his life. Abhartach was then, once again, slain by either another chieftain or an assassin and buried upright. He rose from the dead, once more, the next night, to continue his reign of terror. The chieftain or assassin killed Abhartach one last time. This time, at the suggestion of a druid, they buried him upside down, trapping him in his grave (Bane, 2020, p. 13; Gallagher, 2017, p. 26). As is the case with most modern vampire stories, Abhartach began as a human, returns from the dead, and drinks blood.

\section{Baital (Indian)}

An eleventh-century Sanskrit story, Baital Pachisi, or Vetala Panchevimshati, translated by Sir Richard Francis Burton in the midnineteenth century and renamed to Vikram and the Vampire, is the account of a baital and a king named Vikram. The baital is an evil spirit that can possess the dead, is half-man half-bat with a short stumpy tail. It drinks human blood and devours sacrifices of human flesh. Its gruesome countenance causes those who look upon it to grow weak and faint with fear. When at rest, baitals spend their time hanging from trees near cemeteries (Bane, 2020, p. 28-29). This ancient creature's penchant for hanging from trees and its part-bat form was likely inspiration for literary vampires with the ability to turn into bats.

\section{Berwick (English/Scottish)}

In England's northernmost area, abutting the river Tweed, there was a village named Berwick, or Berwick-Upon-Tweed. Though the town was in England, it came under Scottish rule during the twelfth century. In 1196, there was a prosperous but morally bankrupt merchant who died of the plague. After his burial, written accounts say that he would roam the streets at night, spreading disease as he went and announcing that there would be no peace for the villagers unless his body was set aflame and burned to ashes. The Berwick vampire only left his grave in the evening and returned to it every day before dawn. By the time the villagers exhumed his body and burned it, roughly half of the villagers had perished from the plague (Bane, 2020, p. 33; Summers, 
1996, p. 82-83). The Berwick vampire is an early example of the undead rising from the grave only at night to terrorize the living, much like many literary fiction vampires.

\section{Upyr (Slavic)}

The upyr is an ancient Slavic vampire thought to be created in one of two ways. When a heretic, someone whose beliefs lie outside a religion's dictates, dies, that person might become an upyr. Alternatively, the spawn of a witch and a werewolf would be born an upyr. The methods of killing one bears a striking resemblance to the practices of extinguishing many vampires found in modern literature. The grave of an upyr must be soaked in holy water and a stake driven through its chest. The upyr could also meet its end by decapitation or incineration (Bane, 2020, p. 137-138; Melton, 1994, p. 525).

\section{Vrykolakas (Greek)}

The Greek stories of vrykolakas vary throughout their early history. Initially, they were more spirit in nature than actual physical beings, eventually transforming into the more traditional depictions of the reanimated dead. Vrykolakas were thought to rise from the grave and seek out family members, attacking them and sucking their blood. Burning a vrykolakas is the only foolproof way of destroying it (Bane, 2020, p. 149-150).

\section{Takeaway}

Our takeaway from these early stories of vampiric creatures is that no matter what you call them, they have yet to move from humankind's subconscious to conscious mind-from the realm of myth to archetype. They are representative of Jung's monster myth, and as Campbell claims, born to explain away the unexplainable.

Looking at the vampire myths of early folklore, the question is: What purpose did the creation of the vampire myth serve? Campbell says, "When the story is in your mind, then you see its relevance to something happening in your own life. It gives you perspective on what's happening to you" (Campbell \& Moyer, 1998, p. 4). Many folklore tales start with death and humankind's desire to explain what they did not have the scientific understanding to explain. Suppose a plague or other virus wiped out an entire family or most of a village, with limited knowledge of science and God's wrath having previously taken the form of plagues. In that case, humans might consider it to be God's wrath reigning down on them, that they have done something to earn his displeasure, and they might assume that their place in heaven is in jeopardy. In Jung's book The Undiscovered Self, he states,

It would be an insufferable thought that we had to take personal responsibility for so much guiltiness. We therefore prefer to localize the evil with individual criminals... while washing our hands in innocence...the evil, as experience shows, lies in man-unless, in accordance with the Christian view, one is willing to postulate a metaphysical principle of evil. The great 
advantage of this view is that it exonerates man's conscience of too heavy a responsibility and fobs it off on the devil, in correct psychological appreciation of the fact that man is much more the victim of his psychic constitution that its inventor. (Jung, 2006, p. 96-97)

In other words, if humans create a monster-a myth-which is the perpetrator of their misfortune, they are no longer responsible. This monster is doing the evil bidding of its master, presumably Satan himself. Then humans are not the ones out of favor with God. In fact, by actively setting out to destroy the monster (e.g. through beheading, staking, burning, etc.), they are doing God's bidding and possibly gaining his favor.

\section{From Myth to Archetype}

So how did the vampire move from the realms of myth to archetypes? The Oxford English Dictionary's definition of the word archetype, derived from some of the earliest known uses of the word, "The original pattern or model from which copies are made; a prototype" ("Archetype, n.," 2020), shows that early folklore and literary fiction examples of vampires can give birth to what modern readers would consider a vampire archetype, an original pattern or model. This happens by moving the vampire from the unconscious mind to the conscious mind.

If primitive humans create the monster-vampire myth, from the Shadow archetype, to understand that in which they cannot explain, then what happens to this myth when human intellect evolves? Jung states, "The archetype is essentially an unconscious content that is altered by becoming conscious and by being perceived, and it takes its colour from the individual consciousness in which it happens to appear" (Jung, 1968, p. 20). While the vampire-myth started as an unconscious representation of the Shadow archetype, the numerous accounts in both literary folklore and literary fiction have moved the vampire from our subconscious to our conscious, forming a pattern or a model that forms the basis of three basic vampire archetypes-the vampire monster, the tragic vampire, and the romantic/heroic vampire.

While there are many examples of each of these archetypes in literary and cinematic vampires, for the purpose of this paper, I will give a few examples of each, but I will give most of my focus to one from each archetype.

\section{Defining the Vampire}

To understand the paradigm shift in vampire portrayals, it is necessary to first understand what constitutes a vampire. The origins of the word "vampire" differ from the origins of the lore. The origins of the word are debatable, and accounts of vampirism predate the word itself. In her article "The History of the Word' Vampire,'” Katharina M. Wilson indicates there are four popular theories as to the word's origins; however, she suggests that the more widely accepted roots are Slavic (Wilson, 1985, p. 577). 
The first of these four popular theories come from the late nineteenthcentury Austrian linguist Franz Miklosich. In his book Etymologisches Wörterbuch der Slavischen Sprachen, Miklosich suggests, "[T]he word"vampire" and its Slavic synonyms "upior," "uper," and "upyr" are all derivatives of the Turkish "uber,"-witch" (Wilson, 1985, p. 577).

The second theory favors the idea that a potential source for the word "vampire" is from the root word "pi" or " $\pi i v \omega$," from the Greek verb to drink, combined with the prefix va or av. In his book The Vampire - His Kith and Kin Montague Summers suggests that while this is a possible source for the word, it is an improbable source and that the Greek superstition of the vrykolakas is steeped in Slavic origin (Summers, 1928, 1929, p. 18). Depending on the source, some believe that the Slavic myth of the vyrdolak has Greek origins, while others insist that the Greek vrykolakas has Slavic origins.

The third belief is that the origin of the word is the Hungarian word vampir. This is a popular theory among the English and Americans; however, it is unlikely, given that the first use of the Hungarian word post-dates the use of the term in many Western languages (Wilson, 1985, p. 578).

The most universally accepted source is Slavic in origin. The well-known Grimm Brothers are among the many who favor this theory (Wilson, 1985, p. 577). Though most researchers agree that the word vampire is Slavic in origin, according to Brian Cooper, in his article "The Word Vampire: Its Slavonic Form and Origin," the spellings of the various forms of vampires that begin with "vam" came from the Slavs appropriating the adulterated word back from the Greeks (Cooper, 2005, p. 262).

The Oxford English Dictionary has the earliest English usage of the word vampire from the 1741 text by Charles Forman, called Some queries and observations upon the Revolution in 1688. Their entry on vampires also included the printing of "The Travels of Three English Gentlemen" in The Harleian Miscellany ("Vampire, n.," 2020). While this story was printed in 1745, it relates the travels of three English gentlemen in 1734. From this text:

The Vampyres, which come out of the Graves at Night time, rush upon People sleeping in their Beds, suck out all their Blood, and destroy them... Those who are destroyed by them, after their Death, become Vampyres; so that, to prevent so spreading an Evil, it is found requisite to drive a Stake through the dead Body, from whence, on this Occasion, the Blood flows as if the Person was alive. (Johnson \& Oldys, 1745, p. 358)

While the Oxford English Dictionary gives 1741 as the date of the first use of the word vampire, as its name suggests, this is the first English use of the word, making it entirely possible that one of the four possible origins Wilson notes is the actual origin of the word.

What is important to note is that whatever origin of the word "vampire" that the various linguists believe, none of the origins, as they relate to vampires, predate the late eighteenth century. Yet, stories of vampire lore, stories of those 
with vampiric traits, do. For this reason, the evolution of the vampire, as is discussed in this paper, is referring not only to the creature that is so named but also the creature that is depicted.

The characterization of a vampire is subjective and by no means homogenous. If one were to base their understanding of a vampire on nineteenth-century literature (e.g. Dracula) and select current pop culture (e.g. John Carpenter's Vampires), they might consider a vampire a soulless undead creature who cannot see its own reflection, has two long fangs on the top of its mouth, which it uses to puncture the artery of its victims, and who can mesmerize its human prey. Its weaknesses are garlic, sunlight, staking, beheading, fire, and holy water. However, a look at ancient vampire folklore nets a broader definition of a vampire. Plagues that leave blisters; rabies that causes foaming at the mouth; coma patients thought to be dead but wake up; and possibly sufferers of porphyria, which causes the skin to rash and blister in the sunlight, were all considered evidence of some form of demonic or vampiric possession. This evidence provoked scared villagers to unearth the deceased, stake, and decapitate them-adding more credence to accounts of vampirism. Some of these early reports include exhumed corpses with fingernails and hair that continued to grow what appeared to be new healthy skin, and some stories report evidence of a devoured shroud in the coffin of the perceived vampire. If several family members died in a short time, the townspeople believed that the first to die had awoken from the dead as a vampire and cursed the other members of their families. Causing many people to believe plague victims were vampires (Barber, 1988, p. 34-35). While these early accounts predate the word "vampire," there is a discernable resemblance to nineteenth century and later literary vampire renderings.

Though those early, mostly European, reports of the dead rising from the grave have made their way into many written accounts of vampire sightings, not all vampire researchers believe early vampire folklore are tales of "true" vampires. In his book The Vampire A New History, Nick Groom asserts:

\begin{abstract}
Vampires are not demons, ghosts, wraiths, revenants or witches although their stories are sometimes entwined. Vampires occupy their own distinctive category among bloodsuckers, and likewise they should not be too closely tied to a bundle of generalized fears about the dead, the undead, contagion or death. (Groom, 2018, p. 12)
\end{abstract}

While stories of vampires predating the vampire's ingress into literature encompass expansive characteristics, Groom's suggestions assert that the character traits one might assign to a "true" vampire could be narrower than early folklore suggests. He is not alone in this belief.

Montague Summers, in his book The Vampire in Europe, compares what he considers the "true" vampire to early folklore: 
I would emphasize that the vampiric idea was present among well-nigh all ancient peoples, the one great difference, important enough but not wholly essential, being that whereas the true vampire is a dead body, the vampires of the older superstitions were generally ghosts or spectres, but ghosts were sometimes tangible and spectres who could do very material harm to living people by exhausting their vitality and draining their blood. (Summers, 1996, p. 64)

Though both Groom and Summers denounce vampiric folklore as stories of true vampires, both men include many such stories in their written works on vampires. Therefore, it appears they instinctually understand that taking the irrational fears of primitive humans, born of ignorance of the effects of illness on the human body into account, one could consider a vampire to be any person or creature-more often than not, undead-who steals the life force, in the form of energy, blood, or spiritual essence of a human. At the very least, both men recognize that many modern vampire traits have roots in these archaic vampire renderings. Thus, discounting the idea that these older superstitions are also vampires, as Summers and Groom would have us do, would be a mistake.

One example of an archaic vampire-like story illustrates the epitome of what many would consider vampiric traits. An ancient demon in an Assyrian cuneiform incantation about seven spirits, translated by R. Campbell Thompson in his book Semitic Magic: Its Origins and Development, reads:

Knowing no mercy, they rage against mankind,

They spill their blood like rain,

Devouring their flesh...sucking their veins. (Thompson, 1908, p. 48-49)

Thompson's book includes translations of other texts also describing demons with similar characteristics to vampires. One such verse reads, "Whether thou art an evil Spirit or Evil Demon...Or Phantom of the night, or Wraith of the night...” (Thompson, 1908, p. 98). While these spirits might not fit Groom's or Summer's definition of a true vampire, their influence on the modern vampire construct is evident. Therefore, these early stories of vampirelike creatures should not be overlooked as vampires when trying to understand the nature of vampires.

\section{The Birth of Vampire Literary Fiction and Cinema}

When stories of vampires began to show up in literary fiction, they followed the same pattern of early folklore vampires, in that they were monstrous creatures, lacking a moral compass. However, these vampires often had the ability to mimic humanity; their monstrous side could be hidden. This humanlike vampire is the beginning of the evolution of vampires that ultimately ends in them reaching romantic or heroic status. This is where they start to pull 
away from the Shadow archetype and the mythical representation of vampires that Jung and Campbell speak of. They move from the subconscious to the conscious, becoming their own archetypes.

Vampire literature came into vogue in Europe during the nineteenth century. From folklore and fairytales to Gothic literature, stories of vampires were all the rage. In Fairy Tales of the Russians and Other Slavs, Ace and Olga Pilkington devote an entire section to early nineteenth-century tales of the Undead, translated from their original Slavic languages. These stories mostly lend authority to the idea that vampires are evil creatures - some bearing a remarkable resemblance to Bram Stoker's Dracula. Some of these fairytales could very well have laid the foundation for popular mid to late-nineteenthcentury vampire stories such as "Giaour," The Vampyre, Varney the Vampire, and Dracula. These stories were the start of a new paradigm in vampire representation, where these evil creatures were no longer historical stories of purportedly real creatures one should fear, but fictional stories meant to entertain, thrill, and scare the reader.

\section{Dracula}

By the end of the nineteenth century, the quintessential literary vampire solidified in the form of Bram Stoker's Count Dracula, the progeny of Giaour, Lord Ruthven, Varney, and the like. While some cinematic versions, to some extent, portray him as a romantic seducer, he is still undeniably evil. Yet his tragic story has entranced readers for centuries.

Vlad the Impaler, touted as Stoker's inspiration for Dracula, bears little resemblance to him, other than sharing a name. In Stoker's personal notes for Dracula, there is only a short mention of the name Dracula in reference to Vlad the Impaler. However, in the novel itself, Van Helsing mentions that a scholar friend of his believes "He must, indeed, have been that Voivode Dracula who won his name against the Turk, over the great river on the very frontier of Turkey-land" (Stoker, 2003, p. 285). Yet, other than a thirst for blood-Dracula's being literal and Vlad's being figurative-Dracula shares no characteristics with Vlad the Impaler. In fact, Stoker was initially considering the name Count Wampyr. Stoker notes that the name Dracula means "devil" in the Wallachian language, which is likely the reason for the name change (Eighteen-Bisang, 2008, p. 244-245). His name lends credence to the idea that the fight against vampires is the fight against evil in its purest form. What better name to portray the evil of Count Dracula than a name that claims him to be the devil himself?

Assistant Professor Ani Kokobobo, from the University of Kansas, believes that rather than Vlad the Impaler being the inspiration for Dracula, it is more likely that Elizabeth Bathory, known as the Blood Countess, was his true inspiration ("The Bleeding Truth about Vampires," 2020). While Dracula does have more in common with the blood-draining Countess than Vlad the Impaler, he bears a much closer resemblance to the earlier literary folklore and fiction vampires. 
Dracula was the fulcrum of generations of vampires to come. Stoker's genius was in his ability to combine the most interesting vampiric traits derived from his nineteenth-century contemporaries, as well as earlier folklore, to create a frightening yet fantastical creature whose darkness appeals to humankind's deep-seated dark nature. From his name to his physical and supernatural characteristics, Stoker meant to affect the very picture of a monster when one heard or read the name Dracula. Van Helsing speaks of Dracula's cunning, just as the Bible speaks of the serpent in the Garden of Eden as "more crafty than any other beast of the field..." (English Standard Version Bible, 2001, Genesis 3:1).

Other characteristics of Dracula meant to strike fear in the hearts of mortals are his powers over storms and the dead. He is able to disappear from one location and reappear in another, become mist or dust, traveling on rays of moonlight, and enter a room through the tiniest of crevasses-making escape from him nearly impossible. He can hypnotize humans to do his bidding, as well as command rats, owls, bats, moths, foxes, and wolves, and even transform himself into a wolf or a bat. Perhaps, even scarier for its implications for humans is his ability to become younger when he is well-fed-blood being the only sustenance he needs (Stoker, 2003, p. 281-284).

For all his powers, Dracula is not without his limitations. Though he has the ability to enter a room through tiny cracks, he is unable to enter a place he has not been invited into, but need only be invited once. Then he may continue to enter any time he wishes. Yet another of his limitations is his ability to change form only at noon, sunset, or sunrise. This leaves him more vulnerable if caught in an animal state. He also needs to be near his home soil, which he keeps in coffins in various locations, in order to remain at full strength. Van Helsing informs his fellow hunters of other weaknesses of Dracula. He states:
Then there are things which so afflict him that he has no power, as the garlic that we know of; and as for things sacred, as this symbol, my crucifix... The branch of wild rose on his coffin keep him that he move not from it; a sacred bullet fired into the coffin kill him so that he be true dead; and as for the stake through him, we know already of its peace; or the cut-off head that giveth rest. We have seen it with our eyes. (Stoker, 2003, p. 284)

From the earliest to present-day vampire stories, these monsters are never completely invincible. If they were, there would be no hope for the human race. If vampires started as a myth that our subconscious mind created as the embodiment of our dark nature, then having the ability to overcome the vampire means that we also have the means to overcome our dark nature.

When vampires moved into film, like the early literary vampire stories, the early cinema starts off with completely monstrous vampires, and slowly, endearing qualities are introduced, showing the evolution of vampires from monstrous to romantic continues on in cinema. The silent film Nosferatu: $A$ Symphony of Horror, produced by Prana Films, and directed by F.W. Murnau, 
was the first cinematic depiction of Dracula. Though the vampire character, played by Max Schreck, was named Count Orlok, the similarities between the film and the book were close enough that Stoker's widow, Florence Stoker, successfully sued Prana Film for copyright infringement. Like Count Dracula, Count Orlok had no redeeming qualities.

One of the most famous twentieth-century cinematic versions of Dracula, and the first to include sound, was the 1931 version staring Hungarian actor Bela Lugosi. Not caring to repeat Prana Film's blunder, Universal Pictures secured the rights to produce their adaption of Stoker's story. Dracula may be a monster in deeds in this adaption, but unlike Count Orlok, Lugosi's character is no monster in appearance. This cinematic version is one of the first to incorporate a sexual element into Dracula's visage. Lugosi's character was a handsome man, aristocratic in appearance. His posture remained straight, and his speech clear and concise. His clothes were never rumpled, and he moved with grace and dignity. His focused stare and slow movements towards Mina's neck gave the appearance of a suitor moving in for a kiss, thus cultivating the idea that a vampire's nature might be multifaceted. This perversion of the original Dracula story-that removes some of the sinister traits of Dracula and replaces them with characteristics that viewers can relate to paves the way for the tragic vampire, the tortured antihero.

\section{The Tragedy of Mid to Late Twentieth-Century Vampires}

Early folklore, nineteenth-century, and early twentieth-century stories and cinema introduced the world to the monstrous vampire. However, in the midtwentieth century, a new kind of vampire began to emerge, the tragic vampire. Though they were on the precipice of good and evil, they were worthy of our pity. These creatures were only doing what it is in their nature to do. Most of them never asked for their monstrous fate. They cannot help what they are, and like the Byronic hero, they scorn their very nature and lament their fate. In her article "Rehabilitating Revenants, or Sympathetic Vampires in Recent Fiction," Joan Gordon refers to these vampires as the sympathetic vampires (Gordon, 2011, p. 227-233). Referring to these creatures as sympathetic is a misnomer, though. It insinuates that they feel sympathy for others; however, they are generally self-centered creatures. They bemoan the fact that they are "monsters," that they lack in love, that they have killed to survive. Melancholy would be a better word to describe these tragic creatures who cannot see past their own pain. Literature and cinematic stories such as Dark Shadows, Interview with the Vampire, and Dracula Untold are the bridge between the monstrous and the romantic vampire. For a change from monstrous to romantic to occur, the vampire must first learn to hate its very nature, just as in the bible humankind are told to "Abhor what is evil; hold fast to what is good" (English Standard Version Bible, 2001, Romans 12:9b). One television show, in particular, illustrates vampire self-hatred-Forever Knight. 


\section{Forever Knight}

The 1992-1996 television show Forever Knight follows the story of Nick Knight, a vampire cop living and working in Toronto, Canada. Eight-hundredyear-old Knight was the embodiment of the tragic vampire. His distaste for his state and the atrocities he perpetrated on humans throughout hundreds of years was so overwhelming that he was in a constant battle to fight his nature. Knight did his best to avoid drinking human blood by consuming the blood of animals. He no longer killed indiscriminately, choosing to use his vampiric powers only when necessary-generally in the line of duty. Natalie Lambert, Knight's friend, who is secretly in love with him, is the only human who knows that Knight is a vampire. At the end of the last season, she begs Knight to make her a vampire. He gives in and starts the transformation, but before he completes it, he realizes he cannot subject Lambert to the same fate he has been fighting for so long and allows her to die rather than turning her into what he perceives as his monstrous state. Then in a fit of remorse, he begs another vampire to help him end his life. This Romeo and Juliet-like ending cements the story's place among cinematic tragedies.

What makes vampires like Nick Knight so tragic is that though they despise their very nature, they cannot overcome it no matter how hard they try, just as the apostle Paul says in Romans 7:15, "For I do not understand my own actions. For I do not do what I want, but I do the very thing I hate” (English Standard Version Bible, 2001, Romans 7:15). As this scripture illustrates, humans are no strangers to the fight against their own nature.

Campbell says, "Myths inspire the realization of the possibility of your perfection, the fullness of your strength, and the bringing of solar light into the world. Slaying monsters is slaying the dark things" (148). To which, Moyers asks Campbell, "How do I slay that dragon in me" (148)? In response, Campbell says, "My general formula...is 'Follow your bliss. Find where it is, and don't be afraid to follow it"' (p. 148). Nick's inability to achieve happiness was rooted in his inability to realize the possibility of his perfection.

\section{From Tragedy Comes Romanticism}

While the monstrous vampire archetype dominates early folklore literature and nineteenth-century literature, and the lost and lonely tragic vampire archetype emerges in twentieth-century literature, twenty-first-century literature and cinema gives its audience what the evil turned tragic vampire wants, redemption in the form of the romantic vampire archetype. These vampires were the heroes who overcame their tarnished pasts, which makes this new era of vampires so seductive. Much like man, the modern vampire seeks salvation. In the book The Power of Myth, Bill Moyer calls heaven "[T] hat desired goal of most people" (Campbell \& Moyer, 1998, p. 39). For the vampire to attain this goal, it must become something more than an evil or tragic creature. It must become the hero.

When the romantic hero-like vampire reached its prominence in the literary world during the twenty-first century, writers capitalized on the new craze in vampire stories. This new model of vampires sometimes dedicated themselves 
to the destruction of evil vampires. Campbell states, "Whether you call someone a hero or a monster is all relative to where the focus of your consciousness may be" (Campbell \& Moyer, 1998, p. 127). The focus of the twenty-first-century consciousness was on the need for a hero. Writers exploited this need and seduced the readers into believing that vampires are not evil. These authors mesmerize readers with tales of good versus evil, where good triumphs over evil in the end.

Not only are modern authors creating vampires that are no longer as frightening as their nineteenth-century predecessors, but they are also making completely new rules for what defines a vampire and sometimes how they come into being. Vampires having an aversion to garlic is not guaranteed. Many are not soulless. To name just a few modern romantic vampire series, there are Sherrilyn Kenyon's Dark-Hunter series, Stephanie Meyer's Twilight saga, and Lynsay Sand's Argeneau series-a tale of vampires with unusual origins that perfectly fits with the post-demonic, romantic representation of the heroic vampire.

\section{Argeneau Series}

Lynsay Sands has a unique take on her vampires. The first vampires were Atlanteans, an advanced race of humans whose doctors created tiny nanobots to enter the bloodstream of those with serious illnesses to attack and destroy those illnesses. These nanobots were meant to die off when they finished healing the patient. For all their advanced intelligence, the Atlantean doctors failed to predict that because the human body was always under attack from illness and disease, the nanobots would never die. These nanobots even considered aging to be a disease that needs curing. Any human could become a vampire by the introduction of nanobots into their bloodstream. Once they became a vampire, the nanobots would change the makeup of their genes until they became their perfect age, and their body was in its perfect condition. If an overweight senior citizen became a vampire, they would suddenly find themselves looking and feeling like a healthy 25 -year-old. They became the perfect versions of themselves. These vampire traits appeal to human ideals of physical perfection.

When Atlantis fell, only the Atlanteans with the nanobots inside them survived. However, because the rest of the world was not nearly as advanced as the Atlanteans and didn't have blood banks, the nanobots evolved their hosts to be able to extract blood through their straw-like teeth to get what they needed from other humans. They also evolved their host to be able to read the thoughts of humans, and even other Atlanteans, for the purpose of calming and controlling those they were feeding on.

Just like humans, among her stories, there are virtuous vampires and unscrupulous vampires. Some of these noble and moral vampires take it upon themselves to protect humanity from the wicked ones' intent on committing evil deeds, setting the good vampires up as heroic or romantic figures. While these vampires have super strength, exceptional hearing, enhanced vision, and must drink blood to survive, they by no means resemble the monsters of earlier 
tales. They are no more evil than any other human being. Once civilization advanced to the point of having blood banks, the immortals even created laws against drinking blood directly from humans, rather than bagged blood, except in an emergency, as well as other laws meant to keep them in check and protect humans.

Enhancing the romantic impact of her vampires, Sands gave them each one true love, called a lifemate, for whom they are always on the search. When a vampire met their possible lifemate, they would know them by certain traits. They could not read their lifemate's mind or control them. In Sands's book Vampire Interrupted, the vampire Julius says to his lifemate, "Marguerite, we are lifemates. I can't read or control you" (Sands, 2009, p. 230). This was not the only trait Marguerite and Julius shared that labeled them as lifemates. Lifemates would have shared dreams if they were in close proximity and sleeping at the same time. Unmated vampires, after about a hundred or two years of existence, would lose interest in things like eating and sex. However, if both, or just one of a pair of lifemates, were vampires when they met, they would suddenly find themselves having a renewed interest in both food and copulation. Lifemates were soulmates, and this perfect love was sought-after by most vampires.

These romantic vampires have reached a state that the tragic vampire covets - a state where they are more than just monsters. In becoming worthy of love, the vampire transcends from the monster vampire to the tragic vampire to the romantic vampire. Though the vampire's journey from the monster myth to the romantic archetype parallels humankind's journey from sinner to redeemed, neither vampires nor humans have completely rid themselves of their dark nature. They have suppressed it and allowed the good within themselves to outshine the bad. The New Testament, 1 John 1:8 describes how all people have this darker side, or sin, as it reads, "If we say we have no sin, we deceive ourselves, and the truth is not in us" (English Standard Version Bible, 2001, 1 John 1:8). Though it has a suppressed dark side, the modern romantic vampire has overcome the stigma of the monstrous vampire and despair of the tragic vampire and has metamorphosed from the villain to the hero. When Moyers asks Campbell, "So the hero evolves over time like most other concepts?”

Campbell replies, "He evolves as culture evolves" (Campbell \& Moyer, 1998, p. 135). Like the age-old hero archetype, the vampire has evolved to meet the needs of today's society. It has evolved into the hero.

\section{Conclusion: Out of the Shadow}

Jung's Shadow archetype is the dark side of the human psyche. This dark side gives birth to the subconscious monster myth, with the vampire myth being one manifestation of that monster myth. By moving from humankind's subconscious to conscious mind-going from stories born of generalized fears to fictional literature meant to entertain-vampires moved from myth to 
archetype. In the same way, humans' dark nature moved from unknown to known, or subconscious to conscious, or as Jung says, from the unconscious to the conscious.

The earliest vampire archetype is undeniably a monster. It drains the lifeforce or its victims, sucking their blood and devouring their flesh. It knows no other path than the road to damnation. This monster represents humankind's dark nature, but unlike the vampire myth, this vampire, like some of its human contemporaries, knows its nature and has no desire to be anything other than what it is, a monster.

Like humans, some vampires, once becoming self-aware, became disgusted with who they were and longed to be more, to be made pure. These vampires are the tragic vampire archetype, the vampire who abhors its own existence. It lives a self-sacrificing life out of guilt and a need for redemption. Its repentance comes from a place of fear of damnation and a fear of the monster within.

The third vampire archetype to splinter from the vampire myth and evolve from the monster and tragic vampire is the romantic vampire. The romantic vampire is a protector, a lover, a paragon and has found its salvation in this existence. And though it still carries within a repressed dark nature, what makes the romantic vampire a hero is its ability to resist the temptation to give in to its dark nature, though like humans, it sometimes finds the temptation almost overwhelming. When the vampire evolves from the tragic vampire to the romantic vampire, it has reached its desired state. For Judeo-Christians and many other religions, this would be when they find their salvation. For those of certain other religions as well as those without religious beliefs, this could be when they have reached the pinnacle of who they wish to be.

Just as humans will always have their sinful nature or Shadow self, there will always exist within the three vampire archetypes, a kernel of the Shadow myth, a seed of that sinful nature. The vampire evolves as we evolve. And like humans, not all vampires evolve into this exalted state. Some never leave the monster archetype or the tragic archetype behind, just as literature and cinema have not left them behind.

Campbell states, "What we call monsters can be experienced as sublime... you're climbing, until suddenly you break past a screen and an expanse of horizon opens out, and somehow, with this diminishment of your own ego, your consciousness expands to an experience of the sublime (Campbell \& Moyer, 1998, p. 222). Whether we are talking about vampires or humans, those with the goal of salvation from their monstrous self and who work towards that goal will suddenly find they have reached their destination, and then they can truly experience their bliss. 


\section{References}

archetype, n. (2020). In Oxford English Dictionary. https://www-oed-com.libproxy.dixie.edu/view/ Entry/10344? redirectedFrom=archetype\#eid

Bane, T. (2020). Encyclopedia of Vampire Mythology. McFarland \& Company, Inc.

Barber, P. (1988). Vampires, Burial E Death. Yale University.

Bleeding Truth about Vampires, The. (2020). KU College Stories. http://blog.college.ku.edu/thebleeding-truth-about-vampires-soucouyants-and-the-undead/

Borchiver, R. P. (Producer). (1996). Forever Night [Television Series].

Browning, T. (Director). (1931). Dracula [Motion Picture].

Campbell, J., \& Moyer, B. (1998). The Power of Myth (B. S. Flowers, Ed.). Double Day.

Cooper, B. (2005). The Word "Vampire": Its Slavonic Form and Origin. Journal of Slavic Linguistics, 262.

Eighteen-Bisang, M. E. (2008). Bram Stoker's Notes for Dracula: A Facsimile Edition. McFarland \& Company, Inc.

English Standard Version Bible. (2001). Crossway. https://www.esv.org/

Gallagher, S. M. (2017). The Irish Vampire From Folklore to the Imaginations of Charles Robert Maturin, Joseph Sheridan Le Fanu and Bram Stoker. McFarland \& Company, Inc.

Gordon, J. (2011). Rehabilitating Revenants, or Sympathetic Vampires in Recent Fiction. 29(3), 227-233. https://search.proquest.com/scholarly-journals/rehabilitating-revenants-sympatheticvampires/docview/1304234370/se-2?accountid $=147094$

Groom, N. (2018). The Vampire A New History. Gomer Press Ltd. https://doi.org/10.2307/ j.ctv6gqxp2

Johnson, S., \& Oldys, W. (Eds.). (1745). The Travelsfo Three English Gentlemen: Vol. IV. T. Osborne, in Gray's-Inn.

Jung, C. G. (1968). Collected Works of C.G. Jung (R. Hull, Trans.; 2nd ed., Vol. 9). Princeton University Press.

Jung, C. G. (2006). The Undiscovered Self(R. Hull, Trans.). SIGNET.

Melton, J. G. (1994). The Vampire Book: The Encyclopedia of the Undead. Visible Ink Press.

Murnau, F. W. (Director). (1922). Nosferatu: A Symphony of Horror [Motion Picture].

Pilkington, A., \& Pilkington, O. (2009). Fairy Tales of the Russians and Other Slavs. Forest Tsar Press.

Sands, L. (2009). Vampire Interrupted. Harper Collins.

Stoker, B. (2003). Dracula. Barnes \& Noble Books.

Summers, M. (1929). The Vampire - His Kith and Kin (T. E. K. Paul Trench, Ed.).

Summers, M. (1996). The Vampire in Europe. Random House Value Publishing, Inc.

Thompson, R. C. (1908). Semitic Magic: Its Origins and Development. Luzac \& Co.

vampire, n. (2020). In Oxford English Dictionary: The Definitive Record of the English Language. https://www-oed-com.libproxy.dixie.edu/view/Entry/221303? rskey=Rw0C06\&result=1\#eid

Wilson, K. M. (1985). The History of the Word “Vampire.”JSTOR. http://www.jstor.org/stable/ 2709546 